\begin{tabular}{|c|c|c|}
\hline & KEMAS 16 (2) (2020) 182-191 & GKEMAS \\
\hline & Jurnal Kesehatan Masyarakat & 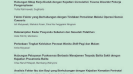 \\
\hline & http://journal.unnes.ac.id/nju/index.php/kemas & $\equiv=$ \\
\hline
\end{tabular}

\title{
The Implementation of Healthy Food Diet for High-Risk Pregnant Woman (AMARIS) Class on the Level of Knowledge and Attitude af Pregnant Woman
}

\author{
Diyah Alva Rina ${ }^{\bowtie}$, Linda Meliati \\ ${ }^{1}$ Department of Midwifery, Poltekkes Kemenkes Mataram, Indonesia
}

\section{Article Info \\ Article History: \\ Submitted December 2019 \\ Accepted Oktober 2020 \\ Published November 2020 \\ Keywords: \\ Amaris Class; \\ Knowledge; Attitude; \\ high-risk Pregnant Woman \\ DOI \\ https://doi.org/10.15294/ \\ kemas.v16i2.22579}

\begin{abstract}
High-risk pregnant women is a period where pregnant women can experience a variety of risks that are influenced by various factors. If a pregnant woman has more knowledge about the high risk of pregnancy then it is likely that mothers will think of overcoming the problem of risk of pregnancy. Healthy Food Diet for High Risk Pregnant Women (AMARIS) class. is one of the means to increase mothers' knowledge and attitudes about pregnancy care. The purpose of this study was to determine the effect of high-risk classes of pregnant women on the level of knowledge and attitudes of mothers about pregnancy care. This study used a pre-experimental research design with one group pretest-posttest, with a total sample of 30 people. The results of the study showed an increase in the average score of knowledge and attitudes after being given a class of resting pregnant women. The average knowledge score before resti pregnant women class was 71.77 , while thereafter increased to 88.22. The average score before resting pregnant women for attitude was 72.66, while after that it increased to 77.83. There is an influence of AMARIS class on the level of knowledge and attitudes of high risk pregnant women with $p$ value $=0,000$. There is an influence of the Amaris class on the level of knowledge and attitudes of high-risk pregnant women.
\end{abstract}

\section{Introduction}

Maternal mortality according to the World Health Organization (WHO) is death during pregnancy or within a period of 42 days after childbirth or the end of pregnancy, due to all causes related to or aggravated by pregnancy or its handling, but not caused by an accident. Based on data from the World Health Organization (WHO) in 2015, the maternal mortality rate (MMR) in ASEAN countries is still much higher, namely Indonesia $98 \%$, Vietnam $62 \%$, Thailand $227 \%$, Brunei $166 \%$ and Malaysia $256 \%$. The MMR in Indonesia is still high when compared to neighboring countries.

Based on the goals in the Sustainable Development Goals (SDGs), maternal and child health are the 3rd GOAL target, namely good health where there are 13 targets including maternal and child health. In the MCH priority to reduce the maternal mortality rate to below 70 per 100,000 live births (LB) by 2030, reduce the Neonatal Mortality Rate to 12 per 1,000 $\mathrm{LB}$ and the under-five mortality rate to 25 per 1,000 LB (Hoelman et al., 2016).

There are still quite a lot of high risk conditions for pregnant women. This could have the potential to have quite a serious impact on both the mother, such as anemia and CED as well as the fetus that will be born, such as low birth weight, birth defects, stunting, and even death. Prevention efforts are needed to reduce maternal mortality. Early detection of pregnancy can be used as an effort to increase woman's knowledge about her pregnancy. Many factors contribute to high-risk pregnancy. Lack of knowledge and awareness of woman about the importance of healthy pregnancy and nutrition during pregnancy is one of the them 
(Asmawati, 2018).

Knowledge is one component of an important predisposing factor for health behavior. If a pregnant woman has more knowledge about the high risk of pregnancy, it is likely that the mother will think about preventing, avoiding or overcoming the problem of pregnancy risk and she has the awareness to have her pregnancy checked, so that if there is a risk during pregnancy it can be handled early and appropriately. by health care personnel. But if pregnant women have less knowledge, the mother will be more at risk in their pregnancy. It is also intended to help reduce the high maternal mortality rate in Indonesia.

The factors causing the high maternal mortality rate in Indonesia are hemorrhage, eclampsia, unsafe abortion, prolonged labor, infection and others. Meanwhile, the indirect causes of maternal mortality are the low level of maternal education, low socio-economic conditions, unsupportive socio-culture, besides that it is due to the limited access of mothers living in rural areas to health services (Aeni, 2013). Often death occurs at the time of delivery, due to bleeding, too young, too old, too close and too much. This condition is then supported by being late in recognizing the signs, being late in reaching the service place and being late in getting help (Puti et al., 2015). Optimal efforts to prevent or reduce the frequency of high-risk pregnant women and their handling need to be done immediately to reduce maternal and child mortality. According to research (Qudriani \& Hidayah, 2017) the perceptions of pregnant woman about high-risk pregnancy that is good will be able to change the mindset, behavior and attitude for pregnant woman to comply with ANC.

Based on monthly MCH data (maternal and child health) in the working area of the Karang Pule Community Health Center there are still many pregnant women with high risk conditions, including CED pregnant women, young pregnant women (less than 20 years), old pregnant women (more than 35 years old) ) as well as pregnant women with comorbidities such as hypertension, diabetes, hyperthyroidism. According to data, pregnant women in CED (Chronic Energy Deficiency) in
2016 were 86 cases (29\%) and in 2017 increased to 100 cases $(40 \%)$. The increasing number is worrying because it increases the risk of birth of LBW (Low Birth Weight) and defects. The condition of LBW babies is more susceptible to disease so that it increases the risk of becoming malnutrition and even death. The handling of LBW babies is also different from babies born normally, so mothers need more time and attention in caring. The number of LBW at Puskesmas Karang Pule in 2016 was 25 cases, increasing in 2017 by 40 (Puskesmas Karang Pule \& Mataram, 2018).

Several factors causing the high number of CED and LBW are the mothers' lack of knowledge about nutrition and health during pregnancy. There are still taboos and food restrictions in the community. The priority of distribution of food in the family has also not benefited pregnant women. Pregnant women and toddlers need to get complete nutrition because in the first 1000 days of life is a golden growth phase, meaning that if there is malnutrition in this phase there will be a disturbance in brain growth and other tissues that can't be restored or permanent. CED pregnant woman is at risk of giving birth to LBW. LBW children are vulnerable to malnutrition. If they grow up and become prospective mothers, they potentially have LBW children too. The cycle will continue as long as it improves in terms of nutrition and health (Asmawati, 2018).

Based on research (Baroroh et al., 2017), there is a significant relation between the knowledge variable and participation in the class of pregnant woman. This is also the same as other research (Ni Nyoman Sasnitiari, Elin Supliyani, Yohana Wulan Rosaria, 2017) that pregnant women who take pregnancy class will have better knowledge and positive attitudes in recognizing pregnancy risks.

Based on the results of interview with the Karang Pule Public Health Center midwife coordinator, it was found that the class of highrisk pregnant woman had been carried out in the Geguntur, of the 11 high-risk pregnant women who participated in AMARIS class, two (2) gave birth to LBW babies and the rest delivered normal weight babies. Handling needs to be done for pregnant women at high risk. 
This AMARIS class activity is expected to be a forum for increasing knowledge and awareness through counseling and improving nutrition by utilizing the capabilities of local materials owned. This study objective is to determine the effect of implementation of AMARIS class on the level of knowledge and attitudes of highrisk pregnant women about pregnancy care. Method

This research is an analytical research with experimental design (quasi experimental) with one group pretest and posttest design and a time series design with a prospective data collection time approach. The study design had no comparison group (control). In this study, observations were made 2 times, namely pre test / before treatment and post test / after treatment to determine the effect of AMARIS class intervention for high-risk pregnant woman on changes in knowledge and attitudes in the work area of Karang Pule Public Health Center. The study population was high-risk pregnant women who were in the working area of the Karang Pule Public Health Center (Karang Seme, Karang Pule and Jempong Barat) during the data collection period from April to June 2019 and a sample of 30 high-risk pregnant women using the purposive sampling method. according to the inclusion criteria.

Data collection is conducted by giving a questionnaire. The questionnaire was administered to each of the high-risk pregnant woman and returned after filling in the pretest or before the intervention was carried out. The questionnaire was filled out by them with guidance of one extension worker at the front of the class who read out one by one the questions in the questionnaire and supervised by the researcher, the midwife coordinator was assisted by a village midwife. Research data collection regarding the knowledge and attitudes of high-risk pregnant women was carried out twice, namely before and after the AMARIS class intervention.

Data analysis was performed using a computer statistical program and univariate analysis to see the frequency distribution of respondent characteristics and knowledge scores before and after the intervention. The attitude score of high-risk pregnant woman before and after the intervention and bivariate analysis were used to analyze the effect of the implementation of the AMARIS class on the knowledge and attitudes of the women about pregnancy care.

The implementation of AMARIS class was adopted from the habits in the community, especially women who like social gathering. Arisan in the form of money collection and given to one in the arisan group selected by lottery system is replaced with a daily diet. The menu is carried out in the evaluation by the participants regarding the quality and quantity of nutrition. Together, pregnant women select, process and serve healthy, fully nutritious and varied foods to meet the nutritional needs of them and their families. The implementation steps are: (1) Nutrition officer and midwives determine environmental priorities for AMARIS activities. (2) Officer contact cadres to collect data on pregnant women in their environment who have high risk. (3) Cadres together with pregnant women make an agreement about the time and place of the arisan meeting. (4) During AMARIS activities, officer facilitate discussions among participants about the topics discussed.

Topics discussed in this AMARIS class are four star nutritious food, food portions for pregnant woman, exclusive breastfeeding, taboos and dietary restrictions for pregnant woman, precautions in pregnancy, the dangers of drugs in pregnancy, personal hygiene and health and the environment. The implementation method used in the AMARIS class is discussion, brainstorming, demonstration and eating together. With this method, it is hoped that pregnant women will not get bored quickly because the meeting was held for 6 meetings with different topic.

The data taken from the research questionnaire were the characteristics of high-risk pregnant woman, knowledge about pregnancy care (four-star nutritious food, food portions for pregnant woman, exclusive breastfeeding, taboo and dietary restrictions, precautions in pregnancy, dangers drugs on pregnancy, personal hygiene and health as well as the environment) and the attitudes of high-risk pregnant woman about pregnancy care. To prove the effect of the implementation of the Amaris class for high-risk pregnant 
woman on knowledge about pregnancy care, the Wilcoxon test was used and the effect of the implementation of the AMARIS class for high-risk pregnant woman on attitudes about pregnancy care the Paired Sample T Test was used.

\section{Result and Discussion}

Based on the results of the study, it was found that the characteristics of high-risk pregnant women, knowledge and attitudes about pregnancy care, the effect of the implementation of the food menu in Amatis class on the level of knowledge and attitudes of pregnant women are as table 1.

Based on Table 1, it showsq that the characteristics of respondents based on age, most were 20 - 35 years old namely 20 respondents $(66.6 \%)$, based on education most of the respondents had basic education namely 15 respondents $(50 \%)$, based on occupation most of the respondents were not working (housewives) namely 29 respondents (96.7\%) and distribution based on parity, most were multipara namely 21 respondents $(70 \%)$.

Table 2 shows that the implementation of AMARIS class in high-risk pregnant woman was carried out in 3 working areas of the Karang Pule Public Health Center, namely the Karang Seme Environment, the Karang Pule Environment and the Jempong Barat Environment The implementation was held in each ward 6 times with different topic on each meeting.

Based on Table 3, it was found that the average knowledge of high risk pregnant woman before the AMARIS class intervention was 71.83 (95\% CI: 66.04 - 77.63), the standard deviation was 15.523 , the lowest was 33.00 and the highest was 100 . The mean value of the knowledge after AMARIS class intervention was 88.22, (95\% CI: 83.92-92.48), standard deviation 11.451, the lowest was 53.00 and the

Table 1. Frequency Distribution of Characteristics of High Risk Pregnant Women in the Work Area of the Karang Pule Public Health Center in 2019

\begin{tabular}{lll}
\hline Characteristics & $\mathrm{N}$ & $\%$ \\
\hline Age & 5 & 16,7 \\
$<20$ years & 20 & 66,6 \\
$20-35$ years & 5 & 16,7 \\
$>35$ years & 30 & 100 \\
Total & & \\
Education & 1 & 3,3 \\
N/A & 15 & 50 \\
Elementary (SD/SMP/Equal) & 13 & 43,4 \\
High School (SMA/Sederajat) & 1 & 3,3 \\
Graduate & 30 & 100 \\
Total & & \\
Occupation & 29 & 96,7 \\
Not Working & 1 & 3,3 \\
Working & 30 & 100 \\
Total & & \\
Parity & 7 & 23,3 \\
Primipara & 21 & 70 \\
Multipara & 2 & 6.7 \\
Grande Multipara & 30 & 100 \\
Total & & \\
\hline
\end{tabular}

Source: Primary Data, 2019 
Diyah Alva Rina \& Linda Meliati / The Implementation of Healthy Food Diet

Table 2. Schedule of AMARIS Class Implementation in the Karang Pule Public Health Center

\begin{tabular}{|c|c|c|c|c|}
\hline \multirow[b]{2}{*}{ Class } & \multicolumn{3}{|l|}{ Location } & \multirow[b]{2}{*}{ Learning Material } \\
\hline & Karang Seme & Karang Pule & Jempong Barat & \\
\hline I & 10 April 2019 & 17 Mei 2019 & 14 Juni /2019 & $\begin{array}{l}\text { Four star nutrition meal, } \\
\text { pregnant woman meal } \\
\text { portion }\end{array}$ \\
\hline II & 11 April 2019 & 18 Mei 2019 & 15 Juni 2019 & Exclusive breastfeeding \\
\hline III & 12 April 2019 & 20 Mei 2019 & 17 Juni 2019 & $\begin{array}{l}\text { Meal prohibition for } \\
\text { pregnnant woman }\end{array}$ \\
\hline IV & 13 April 2019 & 21 Mei 2019 & 18 Juni 2019 & Pregnancy alert \\
\hline $\mathrm{V}$ & 15 April 2019 & 22 Mei 2019 & 24 Juni 2019 & $\begin{array}{l}\text { Medical precaution on } \\
\text { pregnancy }\end{array}$ \\
\hline VI & 16 April 2019 & 23 Mei 2019 & 25 Juni 2019 & $\begin{array}{l}\text { Personal health and hygiene } \\
\text { and environmental health }\end{array}$ \\
\hline
\end{tabular}

Source: Primary Data, 2019

Table 3. Distribution of before and after the implementation of the AMARIS class on the knowledge and attitudes of high risk pregnant women about pregnancy care in the working area of Karang Pule Public Health Center in 2019

\begin{tabular}{lccccc}
\hline Variable & Mean & Median & SD & $\begin{array}{l}\text { M i n i m u m 95\% CI } \\
\text {-Maximum }\end{array}$ \\
\hline $\begin{array}{l}\text { Before Intervention } \\
\text { Knowledge }\end{array}$ & 71,83 & 73.00 & 15.523 & $33.00-100$ & $66.04-77.63$ \\
Attitude & 72,70 & 73.00 & 5.873 & $60,00-88.00$ & $70.51-74.89$ \\
After Intervention & & & & & \\
Knowledge & 88,22 & 90.00 & 11.451 & $53.00-100$ & $83.92-92.48$ \\
Attitude & 77,87 & 78.00 & 6.235 & $65,00-92.00$ & $75.54-80.19$ \\
\hline Source: Primary Data 2019 & & & &
\end{tabular}

Source: Primary Data, 2019

Table 4. The Effect of the Implementation of AMARIS Class on the Knowledge of High-Risk Pregnant Woman About Pregnancy Care

\begin{tabular}{llll}
\hline Variable & $\mathrm{N}$ & Mean Rank & P Value \\
\hline Knowledge Before & 30 & .00 & \\
Knowledge After & 30 & 14,50 & .000 \\
\hline
\end{tabular}

Remark: Wilcoxon test

Table 5. The Effect of AMARIS Class on Attitude of High Risk Pregnant Woman About Pregnancy Care

\begin{tabular}{llllll}
\hline Variable & $\mathrm{N}$ & Mean & SD & SE & P Value \\
\hline Attitude Before & 30 & 72,66 & 5,92 & 1,08 & .000 \\
Attitude After & 30 & 77,83 & 6,25 & 1,14 & \\
\hline
\end{tabular}

Remark: Paired Sample T Test 
highest was 100 . While fot the attitude before the AMARIS class intervention was 72.70 (95\% CI: 70.51-74.89), standard deviation 5,873, The lowest was 60.00 and the highest was 88 . After AMARIS class intervention the attitude score was 77.87 (95\% CI: 75.54-80.19), standard deviation was 6.235 , the lowest was 65.00 and the highest was 92.00 .

The results shows that there is an increase in the knowledge score before and after the intervention with the average value of knowledge increasing by 16,398 points. Increased knowledge of high-risk pregnant woman after AMARIS class is caused by several factors, including activities carried out with the arisan approach, the materials given changes every day, the mother's attention to the material that is delivered every day, the material given is new and rarely heard so that they feels interested, the methods used are discussion, brainstorming, demonstrations, eating together, various media used and the experience that the women had given birth before.

Menurut penelitian (Sorongan Lucia, Atik Purwandari, 2015), didapatkan nilai rerata berdasarkan sebelum pelaksanaan kelas ibu hamil adalah 43.83 dan setelah pelaksanaan kelas 9ibu hamil didapatkan adalah 48,47. Penelitian, terdapat peningkatan kemampuan ibu hamil dalam deteksi dini tanda bahaya kehamilan sebelum mengikuti kelas hamil mayoritas berada pada tingkatan (56\%-75\%) sebanyak 13 responden (43,3\%), diikuti ( $\leq$ $55 \%)$ sebanyak 11 responden (36,7\%), serta $(76 \%-100 \%)$ sebanyak 6 responden $(20 \%)$ dan sesudahnya mayoritas berada pada tingkatan (76\% - 100\%) sebanyak 16 responden $(53,3 \%)$, diikuti (56\%-75\%) sebanyak 9 responden $(30 \%)$, serta $(\leq 55 \%)$ sebanyak 5 responden.

According to a research (Sorongan Lucia, Atik Purwandari, 2015), the mean value obtained before the implementation of the class for pregnant woman was 43.83 and after the implementation was 48.47 . Other research said there is an increase in the ability of pregnant woman in early detection of pregnancy cautions before joining the pregnancy class, the majority are at the level $(56 \%-75 \%)$ of 13 respondents $(43.3 \%)$, followed $(\leq 55 \%)$ ) as many as 11 respondents $(36.7 \%)$, and $(76 \%-100 \%)$ as many as 6 respondents (20\%) and after that the majority are at the level $(76 \%-100 \%)$ as many as 16 respondents (53.3\%), followed (56\% $-75 \%)$ as many as 9 respondents (30\%), and ( $\leq$ $55 \%)$ as many as 5 respondents.

The results showed that there was an increase in attitude scores between before and after the intervention. After the intervention of the AMARIS class, pregnant women had an average score of 5.17 points. It can be influenced by the media used, namely booklets. This research is in line with research (Liska \& Ruhayati, 2018), there is an increase in the average attitude of pregnant women by 4.24 after the class of pregnant woman. Research conducted (Hanum \& Nehe, 2018) majority of high risk pregnant women have positive attitude $(71,4 \%)$ as many as 15 persons and minority as many as 6 persons $(28,6 \%)$

The attitude of high-risk pregnant woman in the AMARIS class is not affected by the characteristics, the positive attitude is affected by the participation in the AMARIS class which increases the woman's knowledge. The good knowledge of the women in the AMARIS class, bring more positive attitude about pregnancy care. Good knowledge about pregnancy care and a positive attitude towards antenatal care are needed so that pregnant women can improve their health and reduce maternal and infant mortality rates. In this study, the expected output of health centers with the presence of AMARIS class in high-risk pregnant women reduces the incidence of LBW. This is expected to reduce MMR and IMR.

The theory states that attitudes will have a direct effect on behavior. The direct influence is more of a predisposition of behavior that will only be realized if the conditions and situations allow. Attitudes will change with obtaining information about an object through persuasion or pressure from social groups. Attitudes are not the same as behavior, and behavior does not always reflect someone's attitude because someone often shows actions that are contrary to their attitudes. Attitude is a closed response whose manifestation cannot be seen directly and is a predisposing factor for behavior.

Based on Table 4, it shows the result of the Wilcoxon Signed Rank Test, the effect of AMARIS class implementation on the 
knowledge of pregnant women, the value of $p=0.000$ is obtained. This means that at $5 \%$ alpha, it can be seen that there is an effect of the implementation of the AMARIS class on the level of knowledge of high-risk pregnant women about pregnancy care in the Karang Pule Public Health Center in 2019 which is very significant between the knowledge of high-risk pregnant women before and after participating in the AMARIS class for high-risk pregnant woman.

The results of this study are in accordance with the government's expectations in the implementation of the class of pregnant women, namely increasing knowledge, changing attitudes and behavior in order to understand about pregnancy checks so that mothers and babies are healthy, safe delivery, comfortable postpartum mothers are safe, healthy babies, prevention of physical and mental illness, disorders. nutrition and complications of pregnancy, childbirth and childbirth so that mothers and babies are healthy, newborn care for optimal growth and development and physical activity for pregnant women (Kementrian Kesehatan RI, 2014).

The AMARIS class for high-risk pregnant women, which aims to increase the knowledge of high-risk pregnant women about nutrition and health so that they have a healthy pregnancy and give birth to a healthy baby and reduce the incidence of LBW. The implementation of the AMARIS class at the Karang Pule Health Center was carried out for 6 meetings with different materials every day so that the participants did n8ot get bored. The topics discussed in this AMARIS Class were four star nutritious food, food portions for pregnant women, exclusive breastfeeding, taboos and dietary restrictions for pregnant women, precautions in pregnancy, the dangers of drugs in pregnancy, environmental hygiene and personal health.

The results of a research (Puspitasari, 2012), found that there was a change in the knowledge of pregnant women or an increase in the level of maternal knowledge after being given pregnancy material with a $p$ value of $0.000<0.05$, the results of this study are in line with other research (Baroroh et al., 2017) mentioned there is a significant relation between the knowledge variable and participation in the class of pregnant woman. A research (Retnaningtyas, 2017) showed that there is an effect of knowledge about the class of pregnant woman on pregnancy care behavior in pregnant women in the working area of Puskesmas Nganjuk and there is a strong correlation between class participation of pregnant woman and primigravida anxiety (Naharani et al., 2018) This is also in accordance with a research (Indah \& Julyarni, 2014), husband's support, woman's motivation and interest have a significant effect on class visits for pregnant woman in Dadaprejo Village, Sengkaling Malang.

According to a research (Septiani, 2013), at the Puskesmas Metro Lampung City, there is a relation between knowledge, attitude of pregnant woman about the class of pregnant woman and husband's support with the participation in the class of pregnant woman. Likewise with research (Syafriani \& Indrawati, 2017), it was found that the lecture and slide methods had an effect on the knowledge of pregnant women in the prenatal class. This is in line with other research (Novadela \& Supriatiningsih, 2012), it was found that there is an effect of the implementation of the mother class program on the knowledge of pregnant women about pregnancy and childbirth in the Banjarsari Public Health Center work area in 2012. Likewise, the results of the study ( $R$ Risneni \& Yenie, 2017) said that there is a significant relation between knowledge and presence, distance of residence, occupation, husband's support, ownership of $\mathrm{MCH}$ books, and parity of pregnant woman in the mother class. But this study is different from a research (Chikmah et al., 2016), indicating that increased knowledge, the attitudes and behavior of mothers in parenting through Mother's SMS Program are more effective than those in the Mother's Toddler Class Program.

Research conducted (Hillier \& Slade, 1989) found of 60 women who attended a class of pregnantwoman showed a significant increase in knowledge after it. This shows 
that the mother's knowledge of high caution signs is not due to age, education, gravida, family support, or sources of information. Woman have good knowledge about the caution signs of pregnancy because of their participation in pregnant woman classes in which they gain knowledge. This is in accordance with a research (Nuryawati \& Budiasih, 2017) mentioned there is a relation between the class of pregnant woman and the knowledge of mothers about the caution signs of pregnancy. Align with a research (Desmariyenti \& Hartati, 2019) found that the factors related to the participation of pregnant women in the mother's class are knowledge, parity, and family support. The results of this study are different from another one (Mulyati \& Djamilus, 2017), there is no significant relation between participation in the class of pregnant woman, but there is a significant relation between husband's support and infant care behavior.

Table 5 shows the results of the Paired Sample T Test. The value of $p=0.000$, which means that at $5 \%$ alpha, there is an effect of the implementation of the AMARIS class on the attitudes of high-risk pregnant woman about pregnancy care in the Work Area of the Karang Pule Public Health Center in 2019 which is very significant between the attitude before and after attending the AMARIS class. The results of this study are in accordance with the results of other study (Meliati \& Ekayani, 2018) mentioned there is an effect of the implementation of the toddler mother class program on the knowledge and attitudes of the mothers in the detection of children's growth and development and there is an effect of the implementation of the mother's class program on maternal attitudes. This research is also in line with other research $(R$ Sihsilya et al., 2016) said the class of pregnant women had an effect on the knowledge and attitudes of mothers practicing IMD.

Based on a research conducted (Hati \& Aryani, 2018), there is an effect of providing education with the class of pregnant woman on the attitudes and knowledge of pregnant women in preventing post partum blues. Research
(Hitatami et al., 2014), showed that health education with short message services can improve the attitudes of pregnant women about high-risk pregnancies, as well as research results (Hanum \& Nehe, 2018) mentioned there is a relation between the attitudes of pregnant woman and high-risk incident pregnancy at the Sunggal Medan Primary Clinic in 2018.

\section{Conclussion}

The results showed an increase in the average score of knowledge and attitudes after being given a class of high-risk pregnant woman. The mean score of knowledge before the class of high-risk pregnant woman was 71.77 , while after that it increased to 88.22. The mean score before the high-risk class of pregnant women for attitude was 72.66, while after that it increased to 77.83. The implementation of the AMARIS class has an effect on increasing the knowledge and attitudes of high-risk pregnant women with a significant increase.

\section{Acknowledgement}

We would like to acknowledge the Director of Poltekkes Kemenkes Mataram, the Mataram City Health Office, the Head of the Karang Pule Public Health Center for all the assistance, support and permission that had been given so that researchers can carry out research as well as all parties who had participated in this research.

\section{References}

Aeni, N., 2013. Faktor Risiko Kematian Ibu. Jurnal Kesmas Jurnal Kesehatan Masyarakat Nasional, 7(10),pp.453-459.

Asmawati, Y., 2018. AMARIS (Arisan Menu Makanan Ibu hamil Resiko Tinggi). Puskesmas Karang Pule Dinas Kesehatan Kota Mataram.

Baroroh, I., Jannah, M., \& Meikawati, P.R., 2017. Hubungan Pengetahuan Ibu Hamil Dengan Keikutsertaan Kelas Ibu Hamil di Wilayah Kerja Puskesmas Jenggot Kota Pekalongan. Jurnal Siklus, 6(2),pp.212-217.

Chikmah, A.M., Laksono, B., \& Yuniastuti, A., 2016. Efektivitas SMS Bunda Dibanding Kelas Ibu Balita Terhadap Peningkatan Pengetahuan, Sikap, Perilaku. Public Health Perspective Journal, 1(1),pp.21-28.

Desmariyenti., \& Hartati, S., 2019. Faktor Yang Berhubungan Dengan Keikutsertaan Ibu Hamil Dalam Kelas Ibu Hamil. Jurnal Photon, 9(2),pp.114-122.

Hanum, P., \& Nehe, K., 2018. Hubungan Pengetahuan dan Sikap Ibu Hamil Dengan 
Kejadian Risiko Tinggi Kehamilan di Klinik Pratama Sunggal Medan Tahun 2018. Jurnal Maternitas Kebidanan, 3(2),pp.81-90.

Hati, F.S., \& Aryani, F., 2018. Efektifitas Kelas Ibu Hamil sebagai Upaya Peningkatan Sikap dan Pengetahuan Ibu Tentang Post Partum Blues. Prosiding Seminar Nasional Vokasi Indonesia, 1,pp.40-46.

Hillier, C. A., \& Slade, P., 1989. The Impact of Antenatal Classes on Knowledge, Anxiety and Confidence in Primiparous Women. Journal of Reproductive and Infant Psychology, 7(1),pp.3-13.

Hitatami, E., Lestari, B., Susanto, H., Hilmanto, D., Dewi, T., \& Sunjaya, D.K., 2014. Pengaruh Pendidikan Kesehatan tentang Kehamilan Risiko Tinggi melalui Layanan Pesan Singkat terhadap Peningkatan Pengetahuan dan Sikap Ibu Hamil. Jurnal IJEMC, 1(21).

Indah, S., \& Julyarni, Y., 2014. Hubungan Dukungan Suami, Motivasi Ibu Dan Minat Terhadap Kunjungan Kelas Ibu Hamil Di Desa Dadaprejo Sengkaling Malang. Jurnal Biomed Science, 2(2),pp.40-48.

Kementrian Kesehatan RI., 2014. Pedoman Pelaksanaan Kelas Ibu Hamil. In Pedoman Pelaksanaan Kelas Ibu Hamil (Edisi Revi). Kementrian Kesehatan RI.

Liska, C., \& Ruhayati, R., 2018. Pengaruh Pelaksanaan Kelas Ibu Hamil Terhadap Pengetahuan Tentang Tanda-Tanda Bahaya Kehamilan Dan Sikap Dalam Pemilihan Penolong Persalinan Di Wilayah Kerja UPTD Yankes Pacet Kabupaten Bandung. Syntax Literate: Jurnal Ilmiah Indonesia, 3(12),pp.27-36.

Meliati, L., \& Ekayani, N.P.K., 2018. Children Under Five Year Mother Class Program to Detect the Children Growth and Development. Jurnal Kesehatan Masyarakat, 14(1),pp.106114.

Mulyati, S., \& Djamilus, F., 2017. Kelas Ibu Hamil dan Perilaku Perawatan Bayi. Jurnal Pendidikan Kesehatan, 6(1),pp.43-49.

Naharani, A.R., Siswati., \& Fatkhiyah, N., 2018. Hubungan Perilaku Keikutsertaan Kelas Ibu Hamil Dengan Tingkat Kecemasan Dalam Menghadapi Persalinan Pada Ibu Hamil Primigravida Trimester III Di Desa Kalisapu Kecamatan Slawi. Jurnal Siklus, 7(2),pp.300306.

Ni-Nyoman, S, Elin, S., \& Yohana, WR.D.A.P., 2017. Hubungan Keikutsertaan Ibu Dalam Kelas Ibu Hamil Dengan Pengetahuan Dan Sikap Terhadap Tanda Bahaya Dalam Kehamilan Di Kota Bogor. Jurnal Kesehatan Reproduksi, 8(2),pp.175-185.
Novadela, N.I.T., \& Supriatiningsih., 2012. Pengaruh Program Kelas Ibu Terhadap Pengetahuan Ibu Hamil Trimester III Tentang Teknik Meneran. Jurnal Kesehatan, IV(2),pp.351-356.

Nuryawati, L.S., \& Budiasih, S., 2017. Hubungan Kelas Ibu Hamil Dengan Pengetahuan Ibu Hamil Tentang Tanda-Tanda Bahaya Kehamilan Di Desa Surawangi Wilayah Kerja Uptd Puskesmas Jatiwangi Kabupaten Majalengka Tahun 2016. Jurnal Bidan Midwife Journal, 3(01),pp.60-66.

Puskesmas Karang Pule, \& Mataram, D.K.K.M., 2018. Laporan PWS KIA Puskesmas Karang Pule. Puskesmas Kota Mataram.

Puspitasari., 2012. Pelaksanaan Kelas Ibu Hamil Puskesmas 7 Bangetayu Kota Semarang. Jurnal Kesehatan Masyarakat, 1,pp.10541060.

Puti, H.S., Dwi, H., Ika, D., \& Nunik, K., 2015. Faktor-Faktor Yang Berpengaruh Terhadap Risiko Kehamilan “4 Terlalu (4-T)" Pada Wanita Usia 10-59 Tahun (Analisis Riskesdas 2010). Media Penelitian Dan Pengembangan Kesehatan, 24(3),pp.143-152.

Qudriani, M., \& Hidayah, S.N., 2017. Persepsi Ibu Hamil Tentang Kehamilan Resiko Tinggi Dengan Kepatuhan Melakukan Antenatal Care Di Desa Begawat Kecamatan Bumijawa Kabupaten Tegal Tahun 2016.pp.15-17.

R-Risneni., \& Yenie, H., 2017. Faktor-Faktor Yang Berhubungan Dengan Kehadiran Ibu hamil Pada Kelas Ibu di Satu Kecamatan Kabupaten Lampung Selatan. Jurnal Keperawatan, XIII(1),pp.19-30.

R-Sihsilya, B.E., Kuntoro., \& Trijanto, B., 2016. Keikutsertaan Kelas Ibu Hamil Berpengaruh terhadap Pengetahuan dan Sikap Ibu dalam Praktik Inisiasi Menyusu Dini. Majalah Obstetri Dan Ginekologi, 24(1),pp.8-12.

Retnaningtyas, E., 2017. Pengaruh Pengetahuan Tentang Kelas Ibu Hamil Terhadap Perilaku Perawatan Kehamilan Pada Ibu Hamil Di Wilayah Kerja Puskesmas Nganjuk. Jurnal EDUMidwifery, 1(1),pp.42-49.

Septiani, R., 2013. Pengetahuan, Sikap Ibu Hamil dan Dukungan Suami Dengan Keikutsertaan Ibu Hamil Dalam Kelas Ibu Hamil di Puskesmas Kota Metro Lampung. Jurnal Kesehatan, IV(2),pp.408-415.

Sorongan, L., Atik-Purwandari, E.P., 2015. Pengaruh Pelaksanaan Kelas Ibu Hamil Terhadap Pengetahuan Tentang Persiapan Persalinan. Jurnal Ilmiah Bidan, 3(1),pp.61-65.

Syafriani., \& Indrawati., 2017. Pengaruh Metode Penyuluhan Deteksi Dini Kehamilan 
KEMAS 16 (2) (2020) 182-191

Risiko Tinggi Terhadap Pengetahuan Ibu Hamil Pada Kelas Prenatal di Puskesmas Bangkinang Kota Kabupaten Kampar.
Jurnal Doppler Universitas Pahlawan Tuanku Tambusai, 1(2),pp.77-86. 